\title{
Quantitative interactomics of Lck-TurbolD in living human T cells unveils $T$ cell receptor stimulation-induced proximal Lck interactors
}

Xien Yu Chua ${ }^{1}$, Timothy Aballo², William Elnemer ${ }^{2}$, Melanie Tran ${ }^{2}$, Arthur Salomon ${ }^{2, *}$

${ }^{1}$ Department of Molecular Pharmacology, Physiology, and Biotechnology, ${ }^{2}$ Department of Molecular Biology, Cell Biology and Biochemistry, Brown University, Providence, Rhode Island, USA

\section{File S1:}

Uncropped Western blot images presented in Figures 2, 3, 4 and 5 
Figure 2 Lck

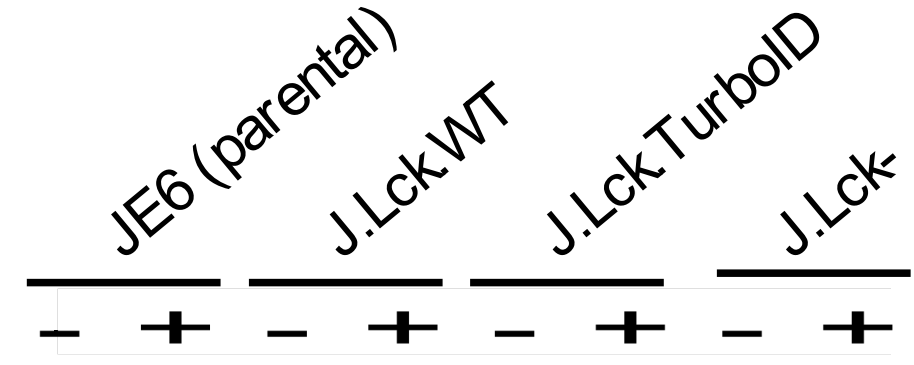

TCR stim. (5 min)

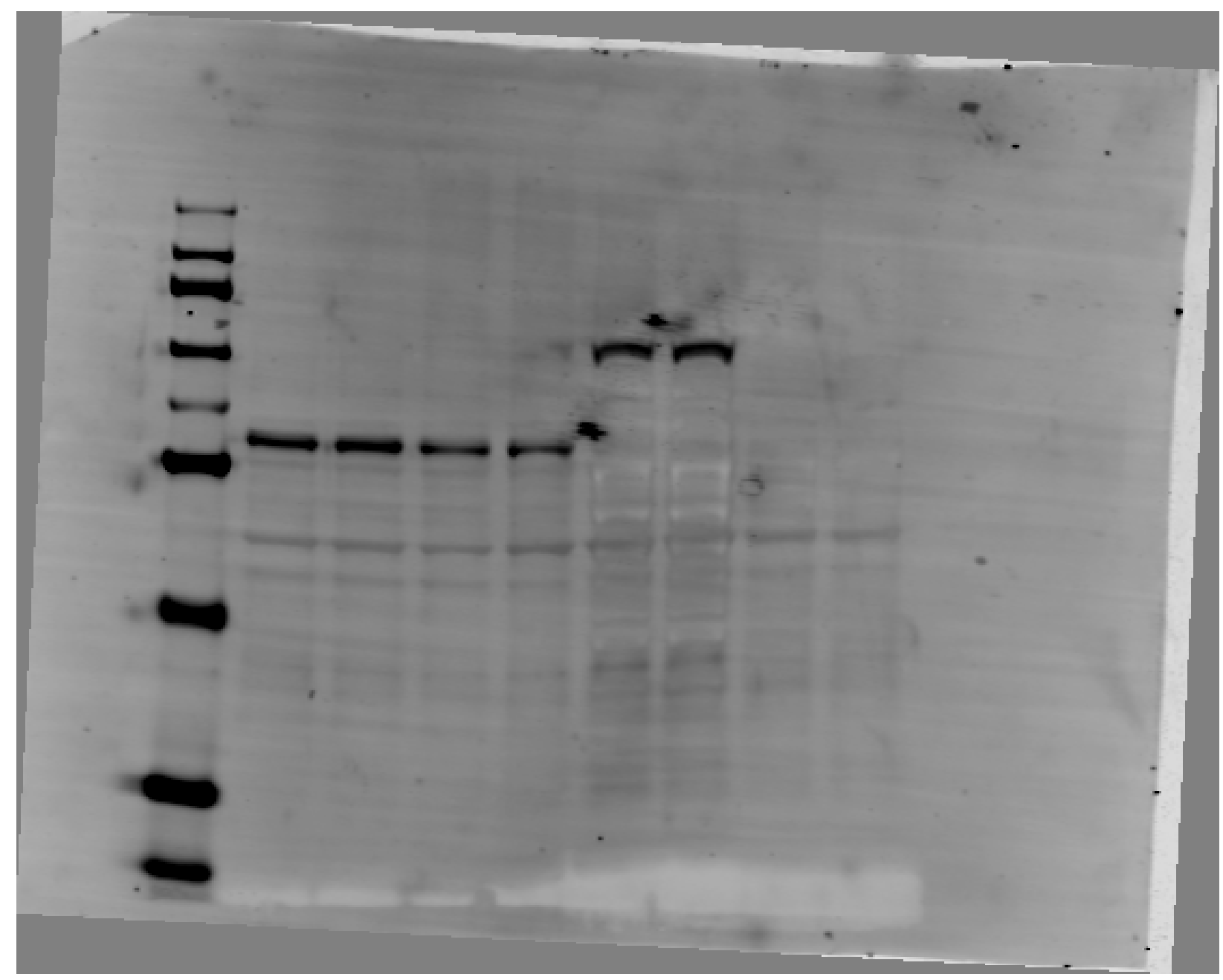




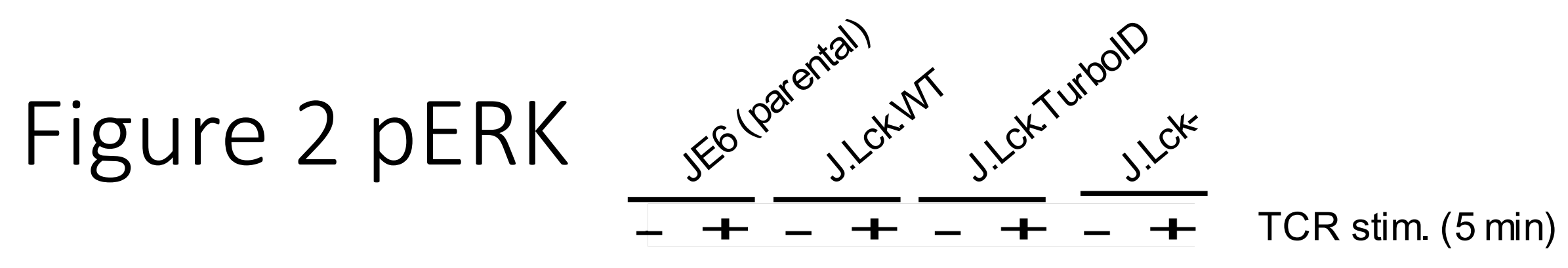


Figure 2 ERK

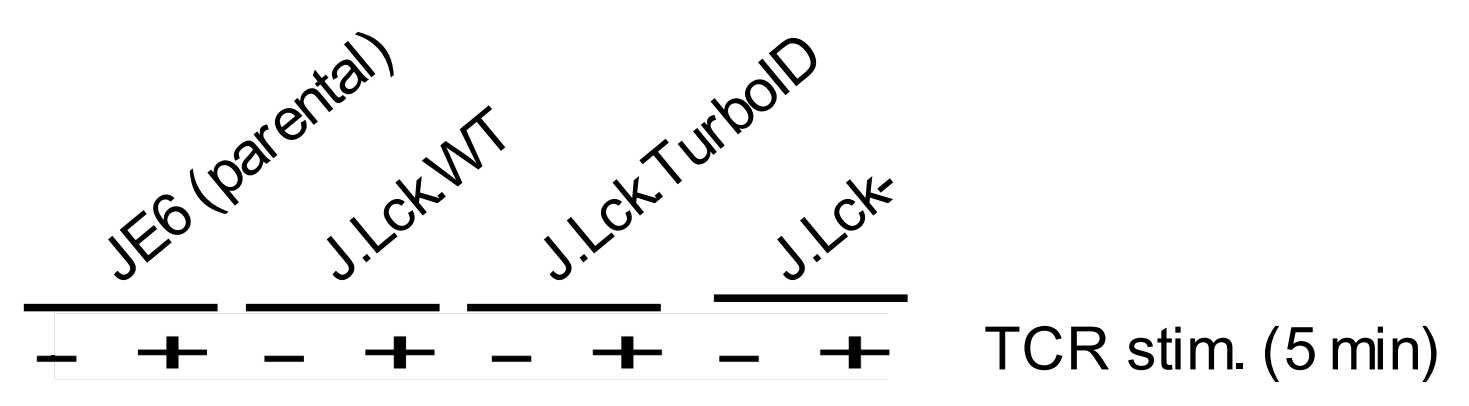

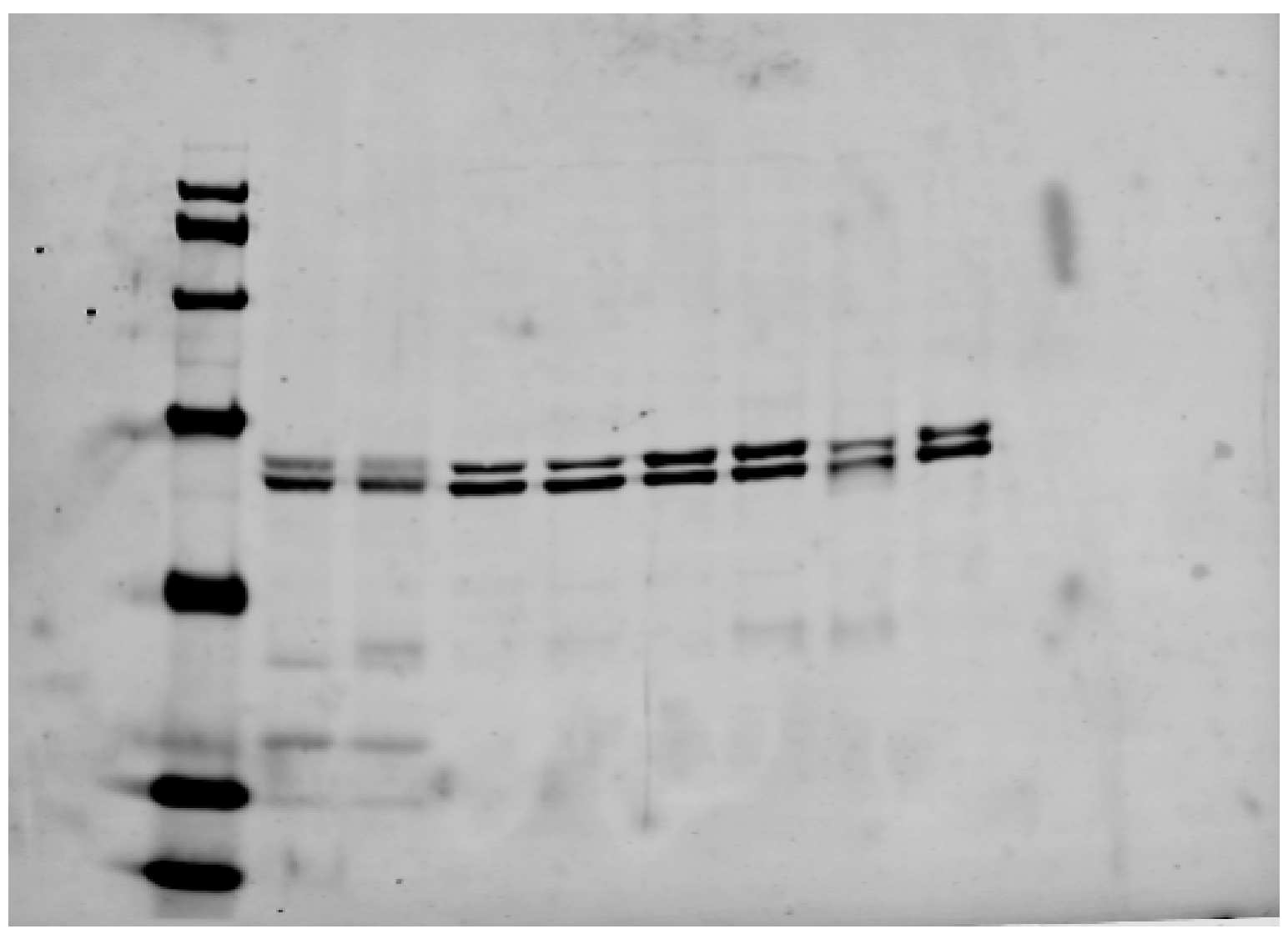


Figure 2 GAPDH
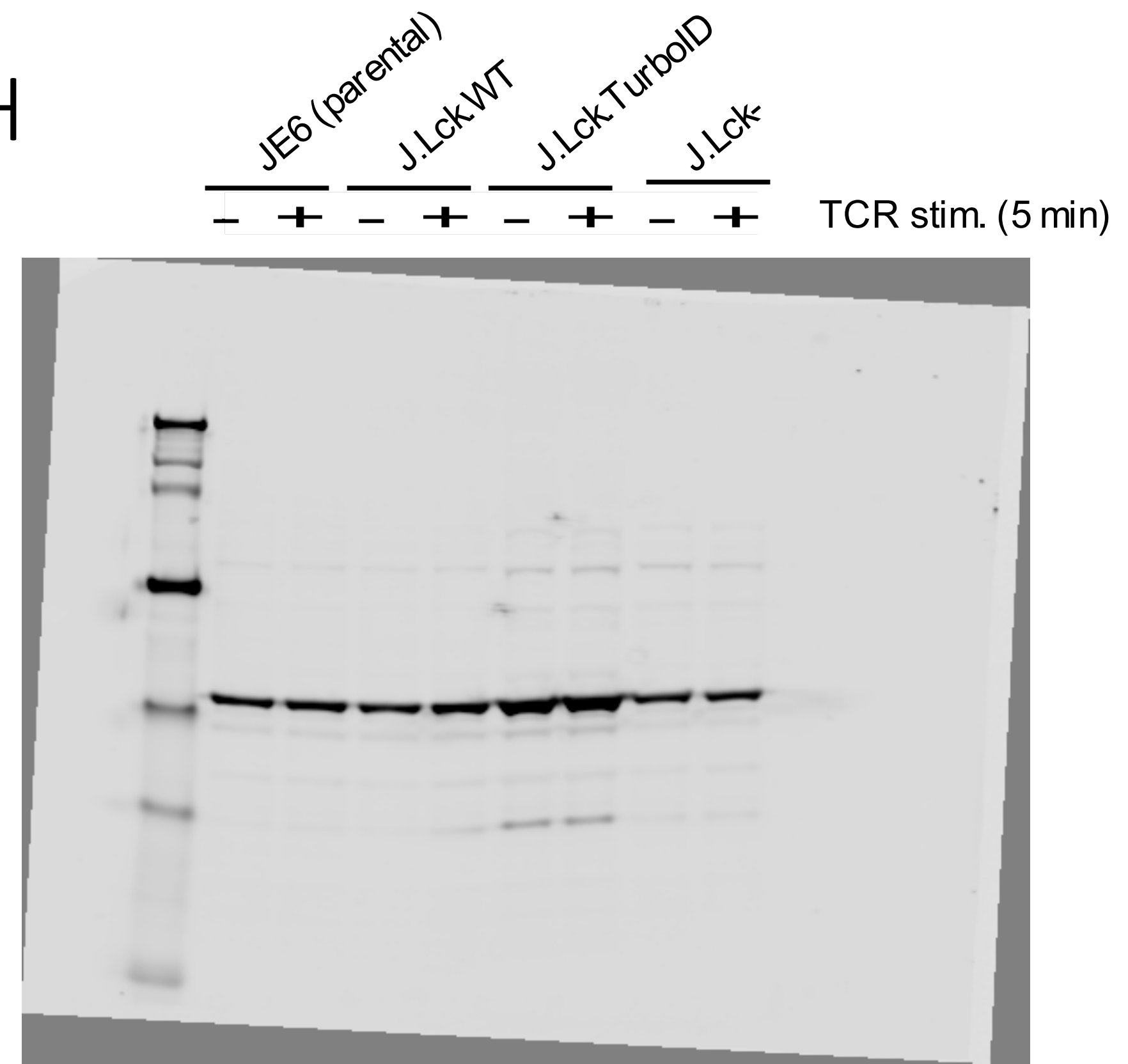
Figure 3A

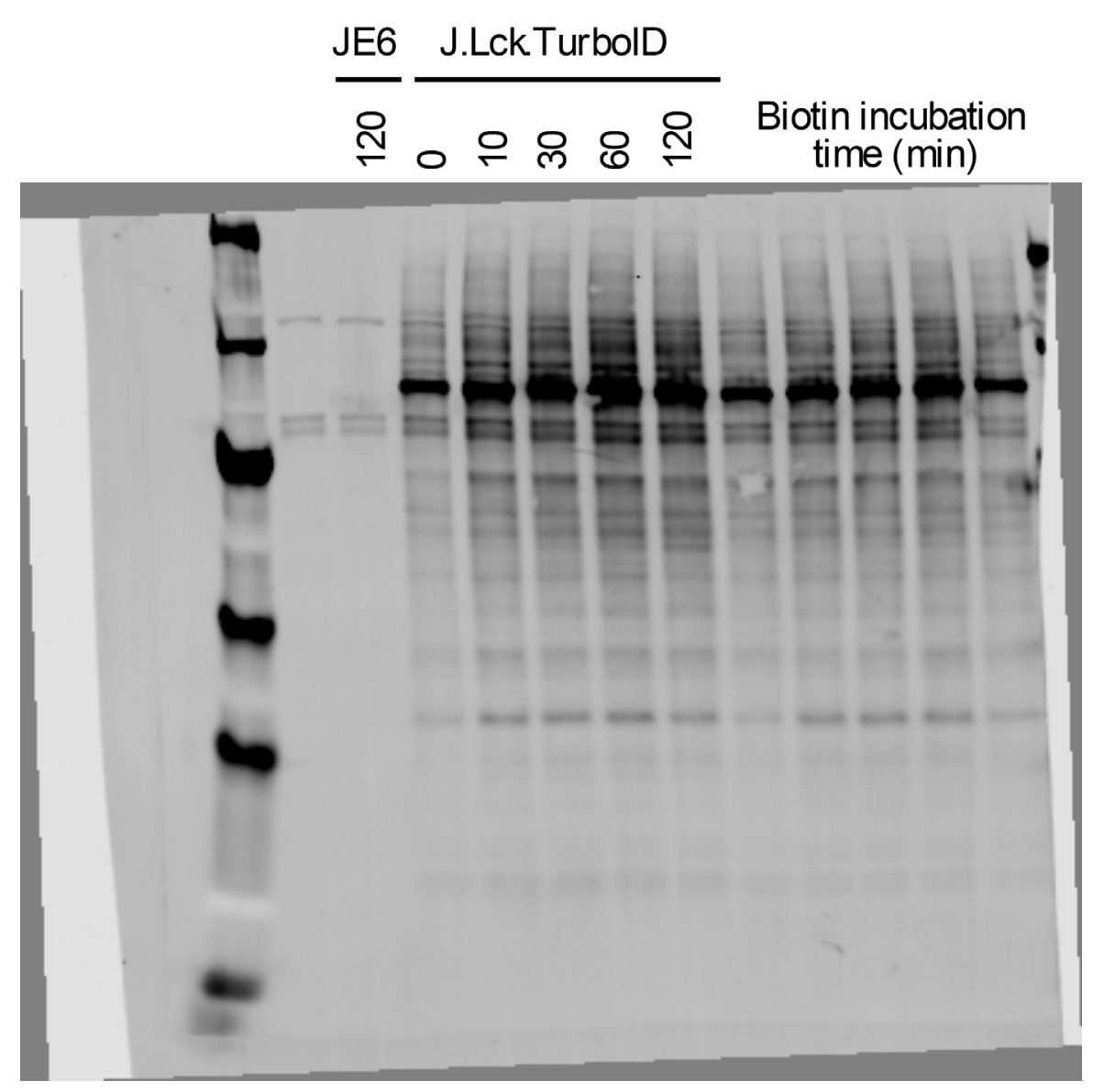

streptavidin

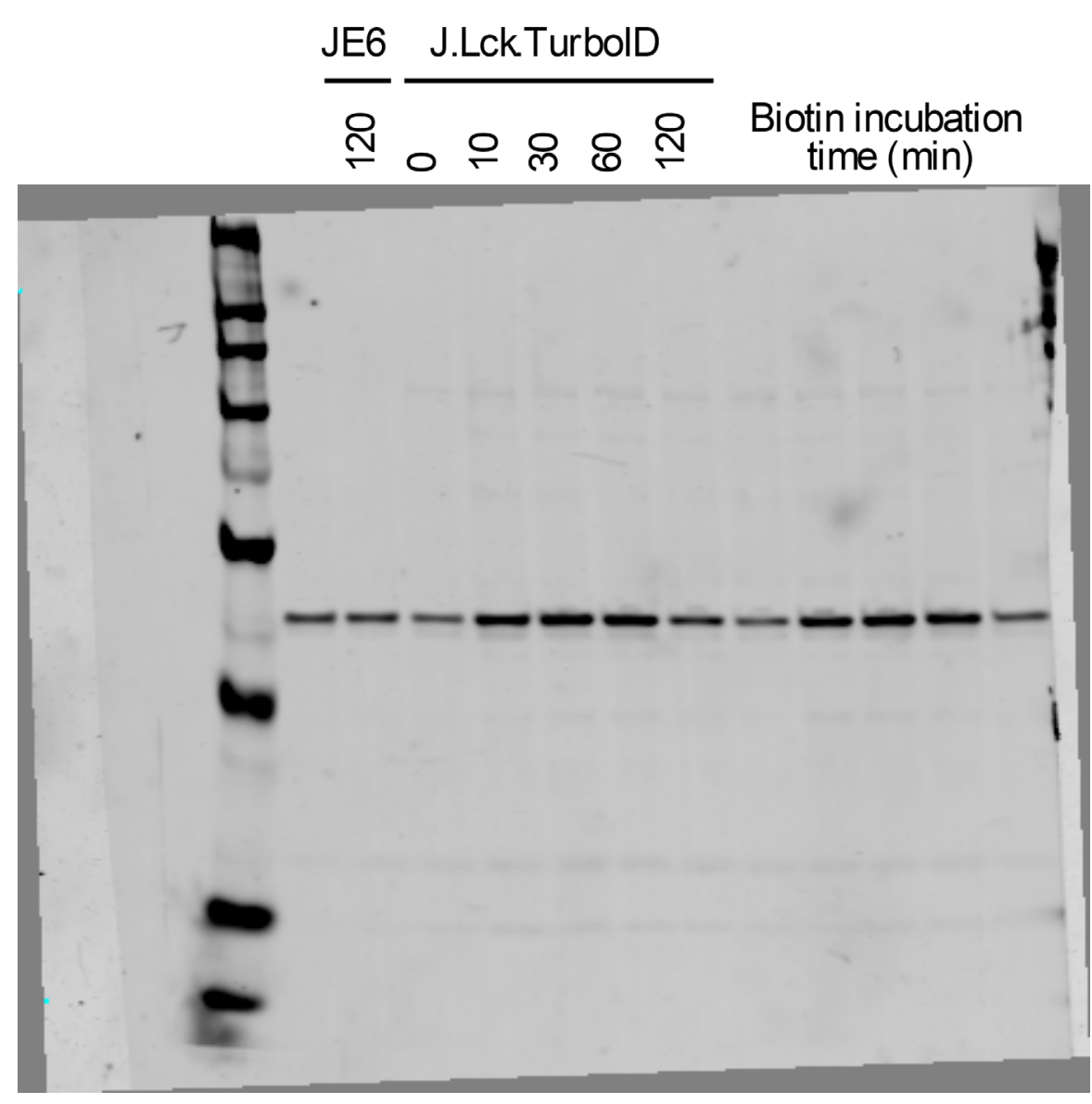

GAPDH 
24-hour Biotin incubation

Figure 3B

$\begin{array}{lll}\frac{\text { 10-min }}{\text { BiolD TurbolD }} & \frac{\text { 6-hour }}{\text { BiolD TurbolD }} \frac{\text { 24-hour }}{\text { BiolD TurbolD }} & \begin{array}{l}\text { Biotin incubation } \\ \text { Lck-X }\end{array} \\ ++++++ & \text { TCR stim. }\end{array}$
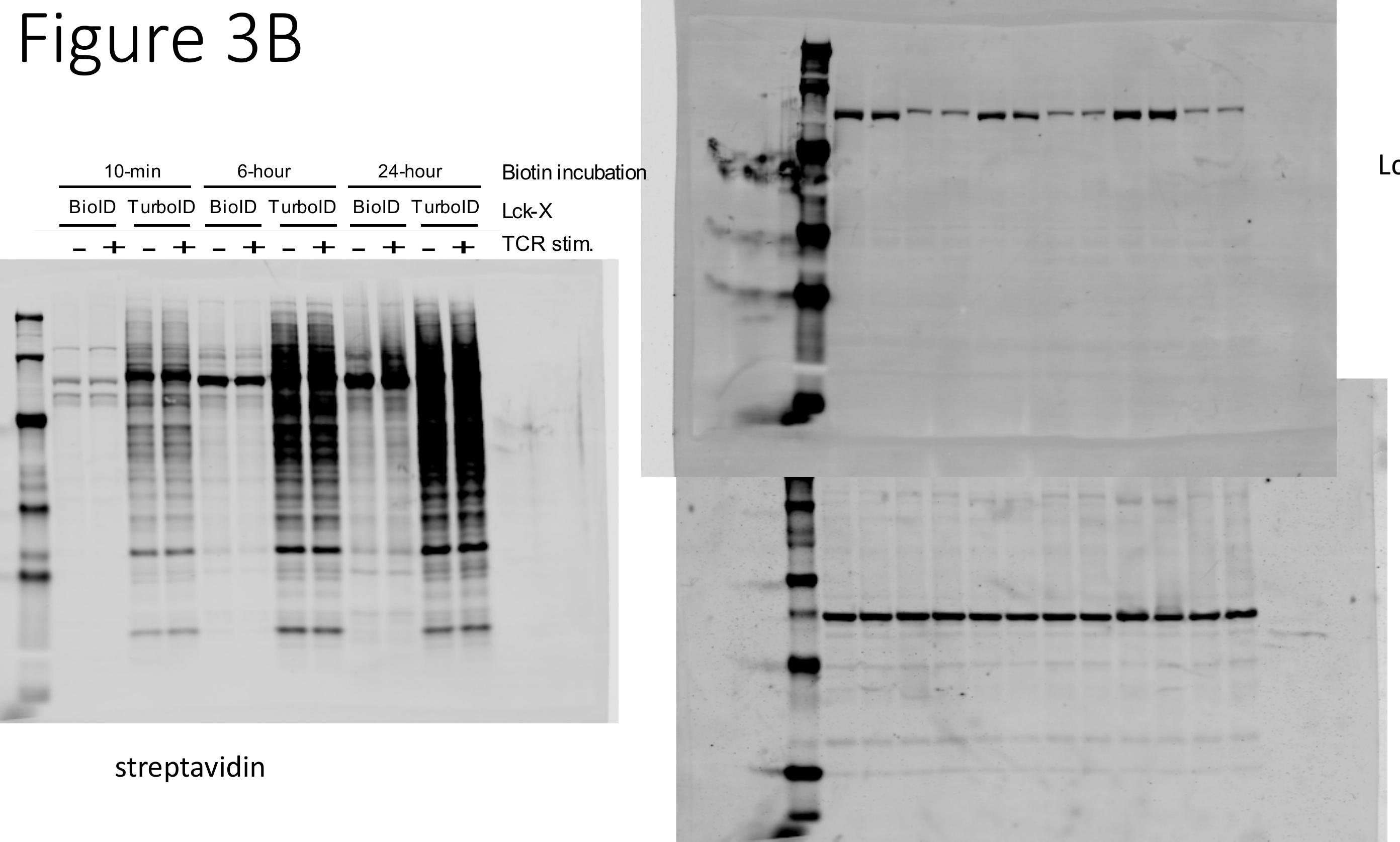

Lck 
Figure 4 Streptavidin
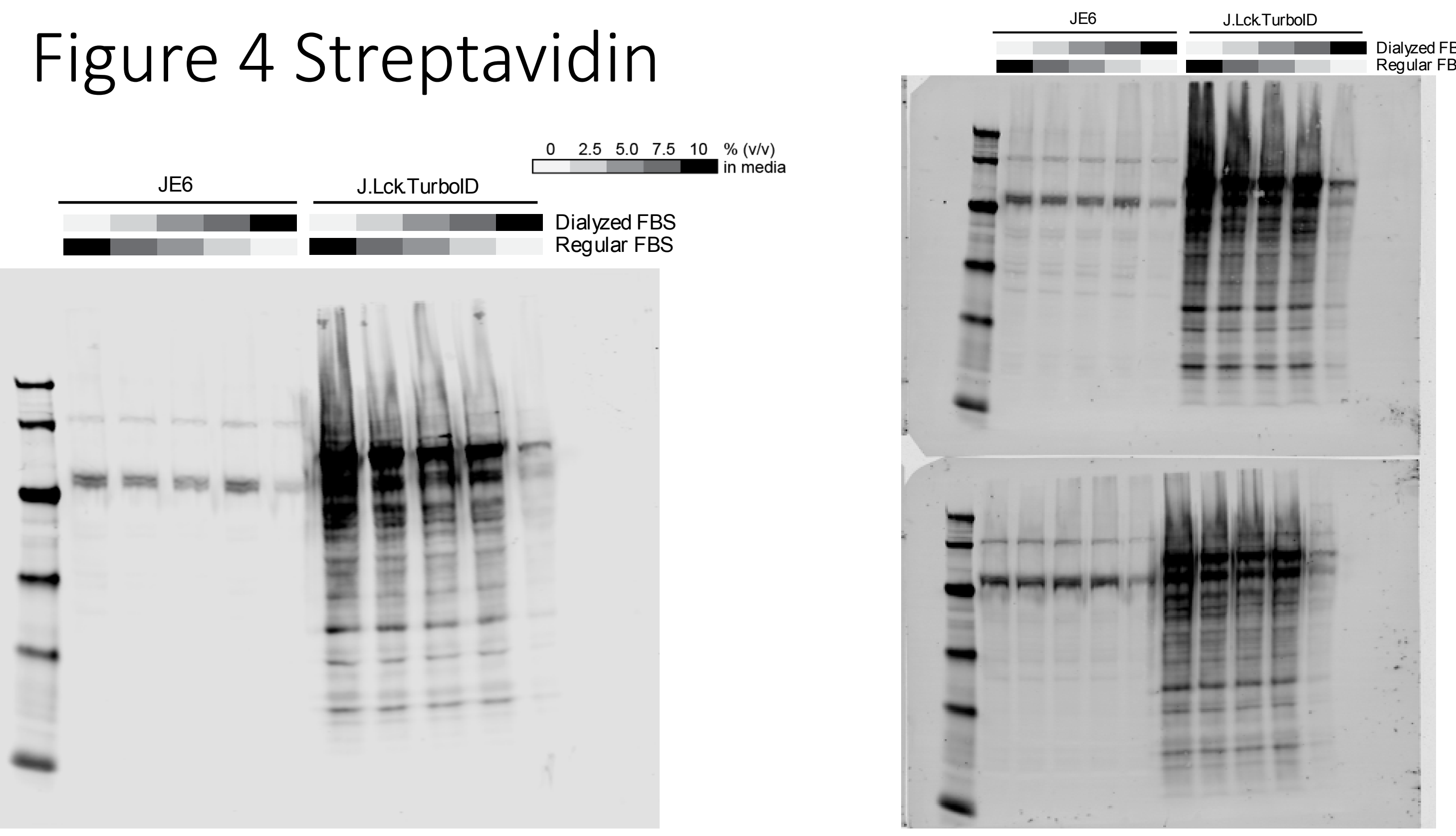
Figure 4 GAPDH

\begin{tabular}{lllllll} 
JE6 & J.LckTurbolD & $\begin{array}{lllll}0 & 2.5 & 5.0 & 7.5 & 10 \%(\mathrm{v} / \mathrm{v}) \\
\text { in media }\end{array}$ \\
\hline & $\begin{array}{l}\text { Dialyzed FBS } \\
\text { Regular FBS }\end{array}$
\end{tabular}

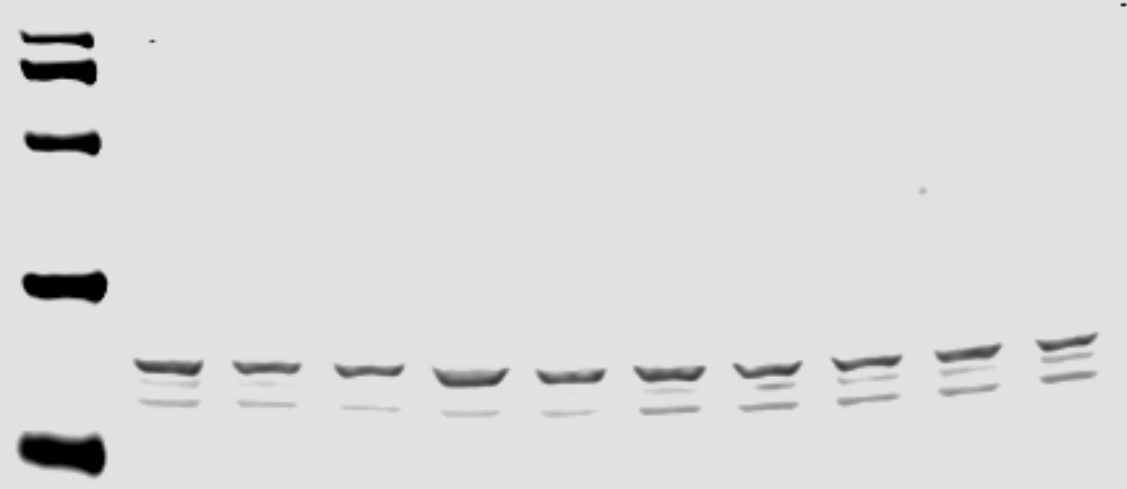

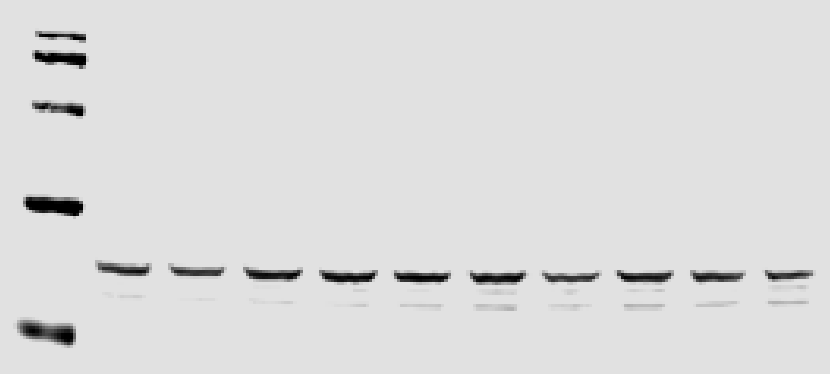

$\equiv$

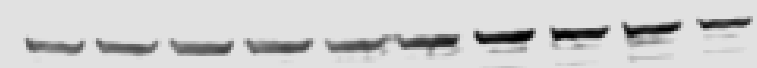
$\infty$

$=$ 
Figure $5 \mathrm{~A}$ $\frac{0 \mathrm{~m}}{-+-} \frac{10 \mathrm{~m}}{-+} \frac{30 \mathrm{~m}}{-+} \frac{60 \mathrm{~m}}{-+} \frac{120 \mathrm{~m}}{-+\mathrm{PV}} \quad \begin{aligned} & \text { Biotin incubation time } \\ & \text { TCR stim. }\end{aligned}$
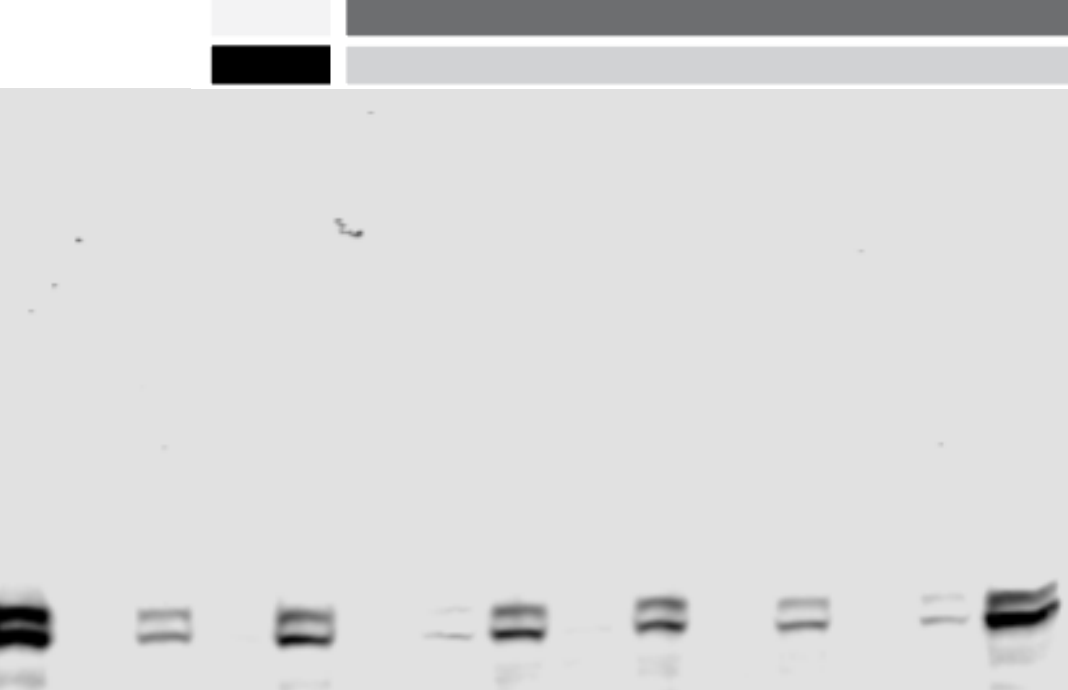

Dialyzed FBS

Regular FBS

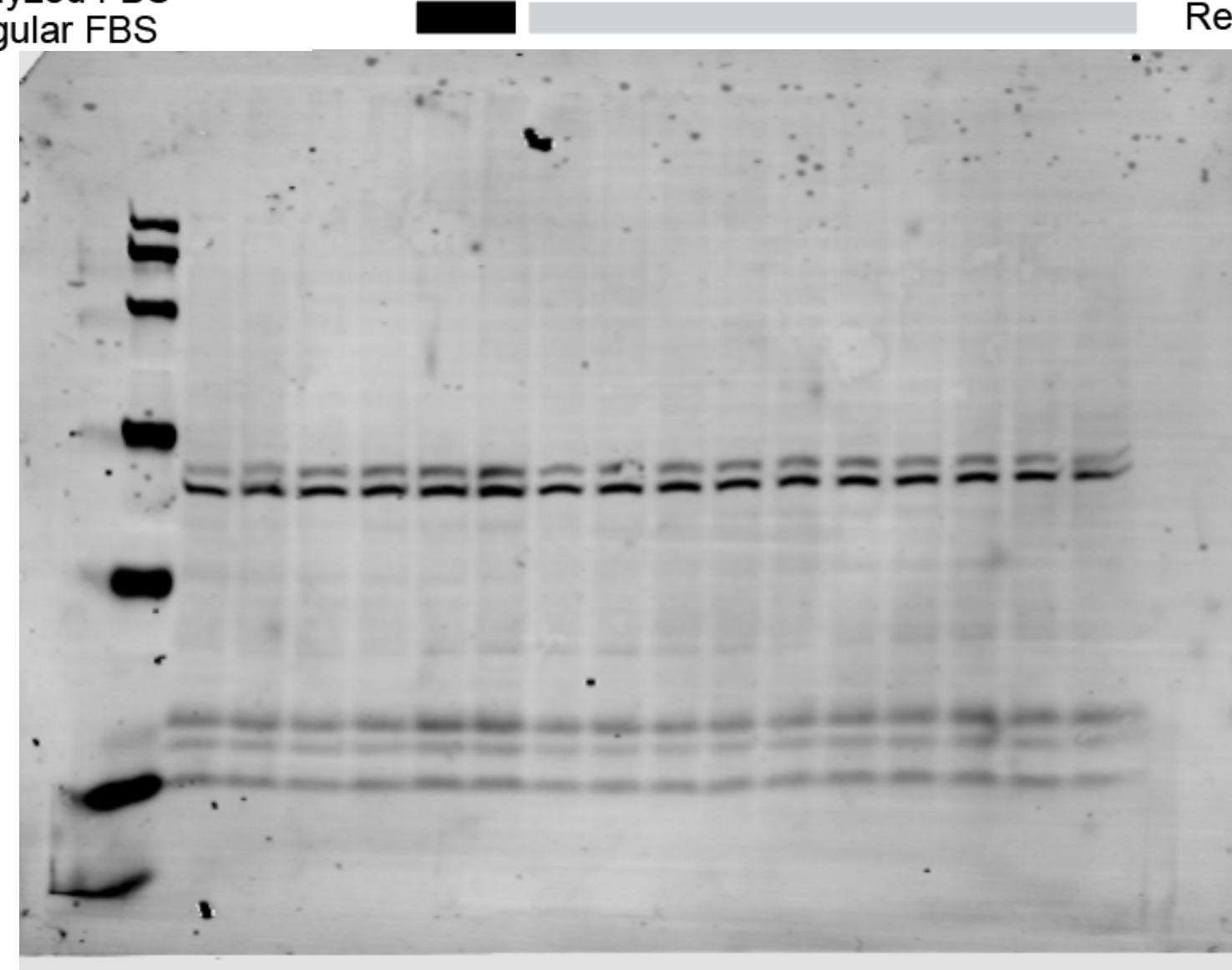

ERK $\frac{0 \mathrm{~m}}{-+-\frac{10 \mathrm{~m}}{-+}} \frac{30 \mathrm{~m}}{-+} \frac{60 \mathrm{~m}}{-+} \frac{120 \mathrm{~m}}{-+\mathrm{PV}}$

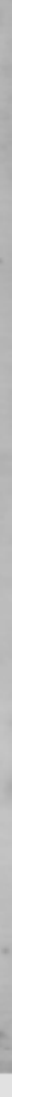

Biotin incubation time TCR stim.

Dialyzed FBS

Regular FBS 
Figure 5B

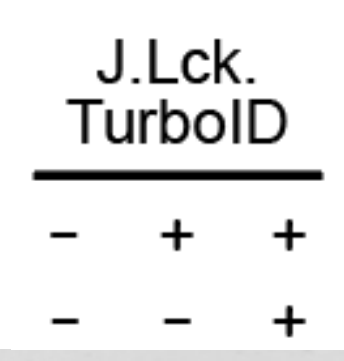

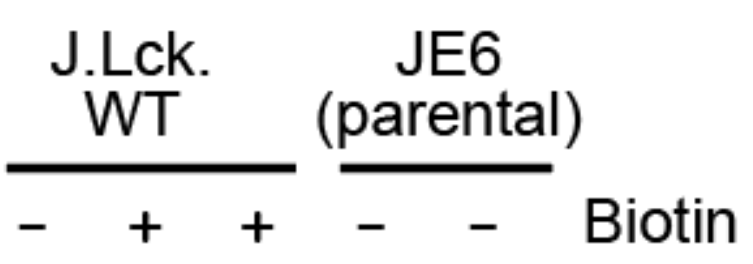

$-\quad+\quad+\quad+$ TCR stim

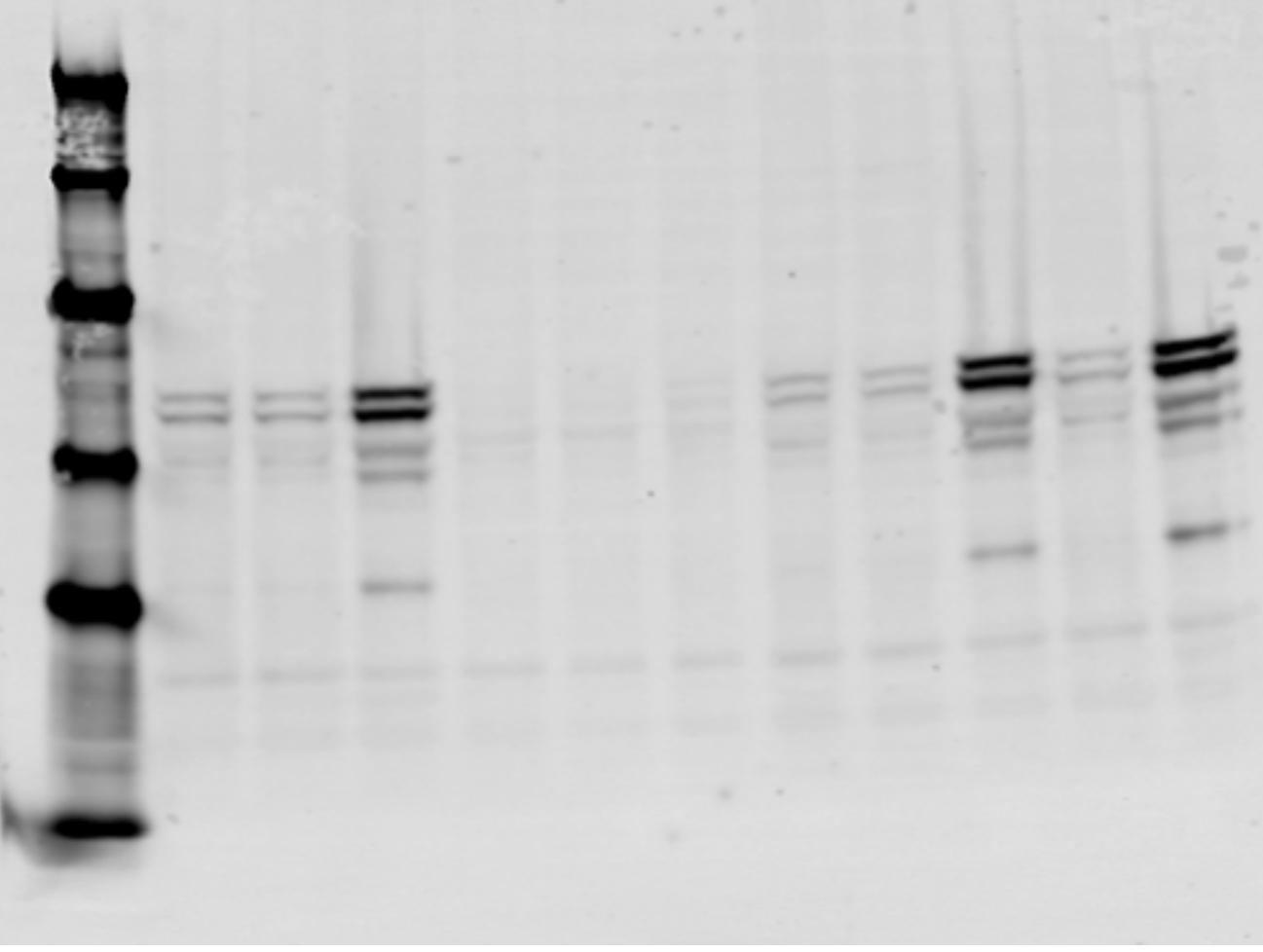

pERK

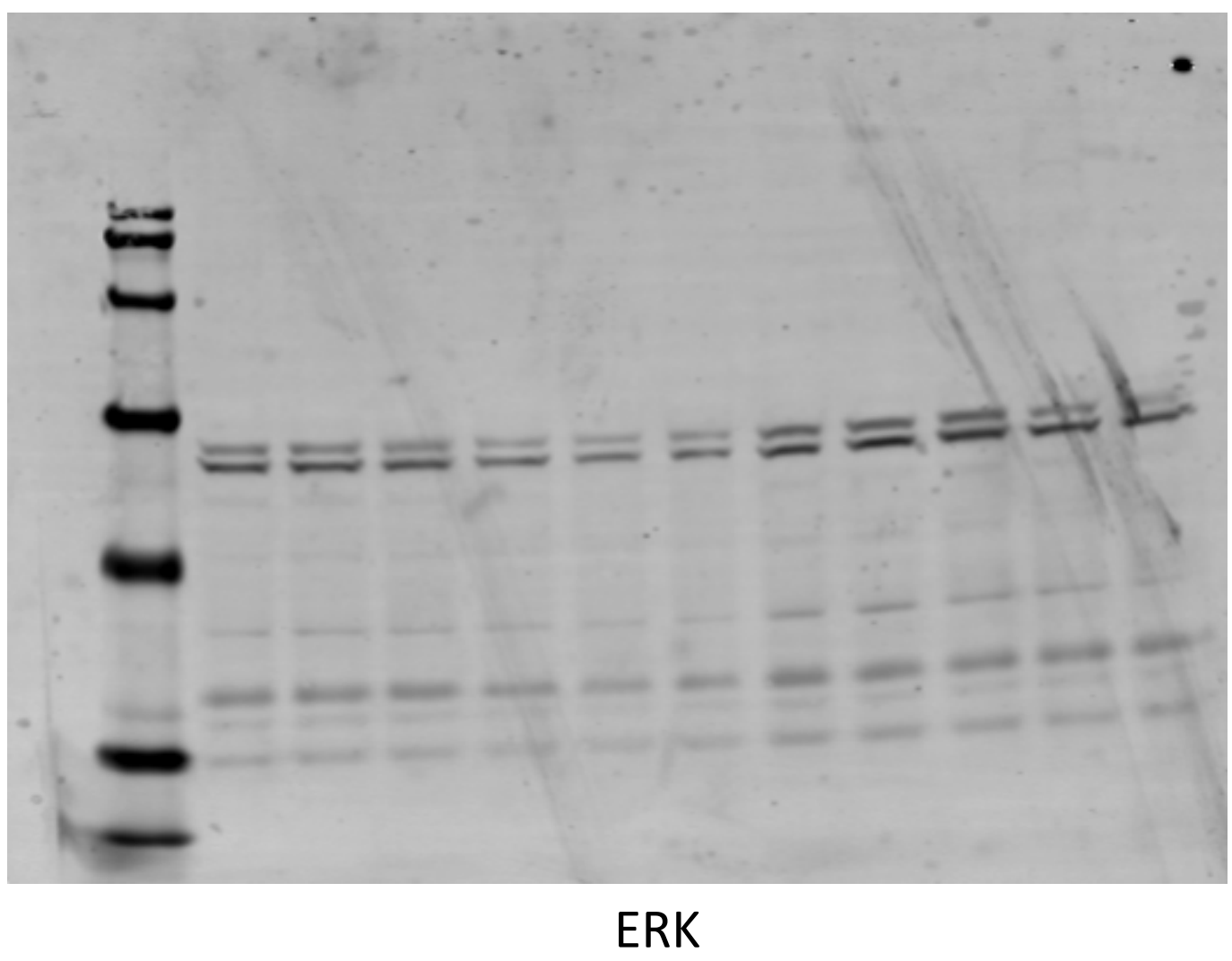


Figure 5B

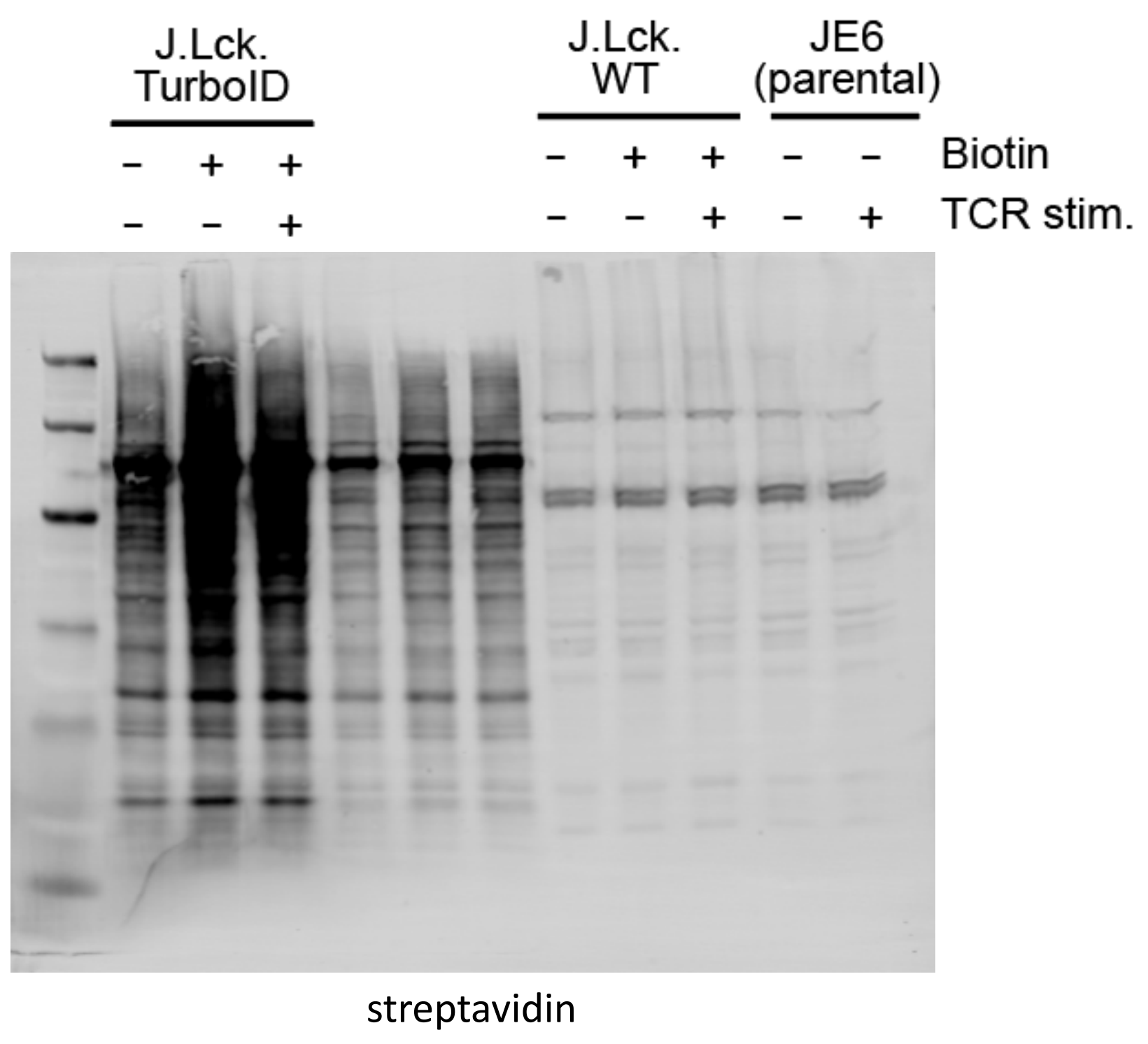

